\title{
Nenhuma história é a História
}

\author{
Nenhuma ilha é uma ilha: quatro \\ visões da litera tura inglesa. \\ GINZBURG, Carlo.
}

São Paulo: Cia. das Letras, 2004. 146 p.

Já não é recente a a mbigüidade do termo História, a o mesmo tempo definindo um processo em constante movimento, comumente chamado de 'a história vivida', e a sua interpretação, ou seja, 'a história conhecimento', conforme a historiografia francesa. Também não é inócua a questão indica da porF. Nietzsche, no século XIX de que a história não passaria de um jogo de interpretações, no qual a História jamais seria 'rea Imente' alcançada. Ou, em outras palavras, o que disse Paul Veyne, no início da década de 1970, em seu livro Como se escreve a história: sempre se faz 'histórias de...' alguma coisa, quer dizer, de determina dos processose assuntos, mas nunca a História.

O historiador italiano Carlo Ginzburg, que inic iou sua ca rreira profissional nos a nos de 1950 e 1960, no interior daquelas discussões, pesquisando processos judic ia is da inquisição dos séculos $X V$ e XVI, principalmente da região do Friuli, na Itália, é um excelente exemplo da forma como, nasúltimas déc a das, ta is disc ussões foram conduzidas. Por meio dessas pesquisas se originaram as obras Os andarilhos do bem e 0 queijo e os vermes. Nas palavras do autor:

Comecei a praticar o ofício de historiador examinando textos não literários (sobretudo processos da Inquisição) com auxílio dos instrumentos interp reta tivos desenvolvidos por estudiosos como Leo Spizer, Erich Auerbach, Gianfranco Contini [...] com o moleiro friula no Domenico Scandela, dito Menocchio, condena do à morte pela Inquisição porcausa de suasidéias, a prendi que o modo como um serhumano reelabora os livros que lê é muitas vezes imprevisível (p. 14).

Em obras como História noturna, 0 juiz e o historiador, ou mesmo em Mitos, emblemas e sina is (livro que reúne a lguns de seus ensaios), o autorse deparou com a questão da interpretação das fontes, da viabilidade das provas e do uso da na rrativa. Além disso, ta mbém se viu obrigado a revisar o estatuto teórico da história das mentalidades e da interpretação marxista da história, para desenvolver seus proc edimentos de a ná lises das fontes e o próprio estilo de sua escrita. No iníc io dosanos de 1970, quando lanç ou seu famoso e polêmico ensaio Sinais: raízes de um paradigma indiciário (que anos depois fol reunido no seu livro Mitos, emblemas e sinais), no qual procurou historiar as origens de seu proced imento investigativo dassociedadese dos homens no tempo, com vistas a analisar as mudanças e as permanências das sociedades passadas e das sociedades presentes, C. Ginzburg já indicava a forma como estava tomando partido naquela polêmica historiográfica. Nas suas palavras:

Retomo àquele ensaio, que desde então tem continuado a alimentar subterra neamente 0 meu trabalho, porque a hipótese sobre a origem da narração ali formulada também pode lançar luz sobre as narrativas voltadas, ao contrário das outras, para a busca da verdade, e contudo modeladas, em cada uma de suas fases, por perguntas e respostas elaboradas de forma narrativa. Lera realidade às a vessas, partindo de sua opacidade, para não permanecer prisioneiro dos esquemas da inteligência: essa idéia, ca ra a Proust, pareceme exprimir um ideal de pesquisa que inspirou ta mbém estas páginas (p. 14).

Mas foi juntamente com Carlo Poni e Geovanni Levi, quando no início da década de 
1980 lança ram um periódic o, a revista Quaderni Storici, e dirigiram a coleção de estudos (reunindo trabalhos de intelectua is italianos, franceses e ingleses) denominada Microstorie, publicada pela editora Einaudi, entre 1981 e 1988, que de fa to C. Ginzburg demonstra ria sua insa tisfaç ões com relação às interpretações macrossocia is indicando, como alternativa necessária à a lteração da esca la de a ná lise do historia dor, os estud os mic rossocia is.

Na década de 1990, entretanto, a o se voltar mais para o gênero ensa ístico e para a a nálise de romances, é que C. Ginzburg indicaria de maneira mais direta sua polêmica com a historiografia pós-modema, na qual seus livros Olhos de madeira e Relações de força formariam suas primeiras incursões nesse debate sobre a histónia estarentre a arte e a ciência. Nesse caso Ginzburg segue os passos da polêmica inic ia da porAristóteles, quando diferenciou a poesia épica da história na Antigüidade clássica, e suas continuidades, em níve is considera velmente distintos, nas críticas veementes de Michael Foucault, Paul Veyne e Hayden White, sobre o esta tuto científico da história, e as respostas de Peter Gay, E. P. Thompson, E. Hobsbawm e Moses Finley sobre essa questã o. A forma como Ginzburg incide na polêmica é sutil, quase sempre sem citar os argumentos e os autores, mas analisando detalhes de um romance (como o de Flaubert), de fragmentos de um diário, ou a inda, estudando os rastros de povos antigos.

Eé justamente seguindo essa forma discreta de polemizar com aquelas questões que em seu novo livro justifica que "talvez [fosse] inevitável que, ma is cedo ou ma is tarde, eu acabasse por me ocupar também de textos literários" (p. 14), não a penas para demonstrar as fragilidades do discurso dito pós-modemo, como ainda ressaltar o uso das fontes literárias para a melhor compreensão das sociedades passadas. Diz o a utor que, ao seguir os traços e a experiência deixada por suas pesquisas anteriores numa "perspectiva semelhante, abordei Vasco de Quiroga, leitor de Luciano e Thomas More; Thomas More, leitor de Luciano; George Puttenham e Sa muel Da niel, leitores de Monta igne; Steme, leitor de Bayle; e assim pordiante. Em cada um desses c asos, procurei analisar não a reelaboração de uma fonte, mas algo mais vasto e fugidio: a relação da leitura com a escrita, do presente com o passado e deste com o presente" (p. 14-15).

Em Nenhuma ilha é uma ilha, orig ina Imente lançado em 1999 em inglês, e em 2002 em italiano, ligeiramente revisto (e a penas em 2004 a pareceria sua tradução para o português pela editora Companhia das Letras), Ginzburg procurou avançar nas discussões acima rapidamente resumidas. Por um lado, recuperou a tradição do gênero ensaístico que vai de Montaigne a Diderot e, por outro, tomou de empréstimo a definição de ensa io ela borada por T. Adomo e as observações sobre esse gênero feitas por Jean Starobinski, lembrando a necessidade de submeter as interpretações a prova e as conclusões às rela tivizações nec essá rias. Nas suas palavras:

Estes ensaios propõem uma visão não insula da literatura inglesa [...] por[meio de] um tema comum: a ilha, real ou imaginária, evocada no título [...] [mas] a unidade do livro não é apenas [...] de ordem temática. Um mesmo procedimento, ou princípio construtivo tem guiado - sem que eu me desse conta de imediato - tanto minhas pesquisas como o modo de apresentá-las (p. 11).

o livro foi dividido em quatro capítulos, articulados por um mesmo tema (e mesmo procedimento interp retativo e narrativo), no qual o autor teria se inspirado nas palavras de J ohn Donne, quando disse que "nenhum homem é uma ilha". Se trocarmosa palavra ilha porhistória, veremosque, na verdade, o que o autorprocurou fa zerfoi demonstrar como o disc urso na rativo dos historiadores é constantemente reescrito. Contudo, nem por isso tal discurso deve ser relega do a uma mińa de rela tivista, porque, a lém de acompanhar as mudanças drásticas e inesperadas da(s) soc ieda de(s), inevita velmente refazendo suas indagações sobre ela, ta mbém é um exercício investigativo no qual a procura de indíciose provas constituiriam a sua função social primordial, já que é a partir desses instrumentos que procura darlógica à análise dos processos e ao mesmo tempo inquirir possíveis laços de identidade, quanto de rupturas, com o passado.

Muito embora reconheça que o que os historia dores fazem não é esc revera História, mas histórias (porque, a lém de serem constantemente reescritas, jamais se conseguiria alcançar a totalidade do 'vivido'), ele acredita que é justamente nesse exercício que o historiador demonstraria sua função social (não por trazerà tona a verdade e sim por mostrar as verdades possíveis e expressas pelos homens do passado) e seu valor perante a sociedade (ao recuperar sua memória coletiva), seja descobrindo ligações entre o passado e o presente que antes não eram vistas, seja demonstrando a ação de indivíduos perante seus pares e a sociedade, ou ainda, refazendo a trajetória de processos ou ações humanas em função de novas descobertas 
investigativas (a partir de provas necessárias à quela s a fimações). E é esse exercíc io histórico e historiog ráfic o, que é um exercíc io a cumula tivo (e sempre complementado), que procurou fazer a o observar a importância de Luciano de Samósata para Thomas More, a polêmica elisabetana sobre a dignidade da rima, os vínculos sutis que ligariam o pároco Laurence Steme, que foi a utor de o Tristam Shandy, a o a teu Pierre Bayle e, finalmente, a possível inspiração que o etnólogo anglo-polonês Malinowski teria recebido com a leitura dos contos do escocês Robert Louis Stevenson.

Em todos essescasos, observa que o regime das trocas literárias oportuniza das entre as ilhas inglesas e o continente europeu foi decisivo na formação tanto da literatura inglesa quanto de sua identidade nacional. Por outro lado, registra a importância do detalhe, colhido muitas vezes quase que ao acaso, para se reconstituir um processo, porque foi “o acaso, não a curiosida de deliberada, que me fez dar com os comentários do bispo Vasco de Quiroga à Utopia de Thomas More ou com a Defesa da rima de Samuel Daniel" (p. 11). É por isso que indica que com o gênero ensa ístic o existiria a flexibilida de necessá ria para a construção da narrativa. Nas suas palavras:

Mas talvez essa mesma flexibilidade tenha êxito em captar configurações que tendem a escapar às malhas das disciplinas institucionais. Talvez seja instrutiva a divergência entre Quentin Skinner e este autor a propósito do gênero a que pertenceria a Utopia de Thomas More. Seria possível objetar que a Utopia constitui um caso especial, tratando-se de um dos raros textos que inauguraram um gênero literário. Mas eu me pergunto por qual motivo uma polêmica à primeira vista técnica sobre a dignidade da rima, que irrompeu na Inglaterra elisabetana, foi treslida a ponto de se ignora rem suas raízes continenta is, a começar por Montaigne. Seria muito fácil encontrar muitos casos do mesmo teor (p. 13).

Eé justamente sobre isso que o autorchama a atenção de seus possíveis leitores do início a o final de seu texto, pois nenhuma ilha é uma ilha poderia ser lido como nenhuma história é a História (e, por isso, o discurso histórico é tão incompleto e fugidio, e às vezes também impreciso, porfalta de fontes que o comprove). Nas sua s palavras:

Nos dois primeiros ca pítulos fa lou-se de ilhas ilhas inventadas, como a de Utopia, ou reais, como a Inglaterra - de uma perspectiva não insular. Contra o lugar comum corrente segundo 0 qual todas as narrativas pertenceriam em alguma medida à esfera da ficção, procurou-se mostrar que existe uma relação complexa entre as narrativas inventadas e as narrativas com pretensão à verdade. A ilha imaginada de Utopia permitiu que Thomas More percebesse (e denunciasse) a s extra ord iná ria s tra nsforma ções em curso na sociedade inglesa. A defesa da rima como procedimento literário diante das acusações de barbárie tinha lugar em uma ideologia imperialista nascente, voltada a acentuar a distância cultural e política entre as ilhas britânicas e o continente europeu. Verdade e ficção, examinadas de uma perspectiva não insular, encontram-se igualmente no centro deste terceiro capítulo, dedicado a o Tristam Shandy de Laurence Steme (p. 64).

No último capítulo do livro Carlo Ginzburg pratica com maestria esse procedimento, ao demonstrar os possíve is c onta to entre Ma linowski e Robert Louis Stevenson (principalmente com seu conto 0 demônio da garrafa), quando este desenvolvia sua interpretação do kula sobre as tribos das ilhas de Trobriand:

O kula, escreveu Malinowski nos Argonautas, refutava as idéias, então correntes, que viam no homem primitivo um 'ser racional que não deseja outra coisa além de satisfazer as necessidades mais elementares, segundo o princípio econômico do mínimo esforço. (Malinowski prova velmente ignorava que tinha Marx a seu lado). Mas as implicações da descoberta de Malinowski ultra passa vam em muito o âmbito da chamada 'economia primitiva', como mostra a sua progênie tardia, do ensaio de Mauss sobre a dádiva à Grande transformação de Polany, ou o ensaio de E. P. Thompson sobre a economia moral (no qual, todavia, a ligação é ma is indireta). 0 que de fato estava em jogo era a noção de homo oeconomicus, ainda hoje bem viva. Mas o a rquipélogo de Stevenson e o de Malinowski estão ali para noslembrarque nenhum homem é uma ilha, nenhuma ilha é uma ilha [e podería mosa crescenta rque nenhuma história é a História ] (p. 113).

Nesse sentido, a leitura desse livro é enriquecedora por pelo menos três pontos: a) para nos dizer que a história é constantemente reescrita, porque as mudançasdoshomense das sociedades no tempo exigem novas investigações e questionamentos para se identificar adequadamente o que ainda se manteria do passado no presente e o que mudou; mas nem por isso o disc urso dos historia dores esta ria imerso num relativismo, no qual não haveria mais a 
procura de possíveis verdades; b) não é a penas de verdades que é feito o discurso dos historia dores, visto que, se as fontes forem mal ou insuficientemente interpretadas, em casos extremos elas podem sugerir mentiras, que, ao serem transp ostas a o disc urso dos pesquisa dores, podem vir a ser uma verdade; c) mas, mesmo assim, a função social básica do historiador é, senão a descoberta da verdade (ou das possíveis verdades) que nos legaram as sociedades passadas, ao menos a inclinação à procura de verdades (demonstrando-se que em algunscasos a mentira, que não é um mero detalhe nos processos históric os, pode se tomaruma verdade construída pelo discurso). De forma mais direta, o autor quer demonstrar a importância dos historia dores para as socieda des na construção de suas identidades, talvez até mais no período atual do que no passado. Para isso, indo contra a ma ré dita pós-modema, sugeriu nesse livro que o disc urso literário pode ta mbém serum c a minho, quando bem analisado seu processo de elaboração e, com isso, cotejadas suas provas, para se esc reverum disc urso históric o verda deiro (entre outros possíveis) sobre as sociedades e os homens no tempo. Isso porque a história é constantemente reescrita, fazendo com que nenhuma história seja a História, mas nem por isso não seja uma história. É justamente nesse ponto, aclamado como o inevitável relativismo do discurso e da verdade (a ponto de alguns estudiosos a credita rem que ou ela não existe, ou é a penas uma construção disc ursiva), segundo a crítica dita pós-modema, que para o autor se encontrariam a função e a importância dos historia dores, não rela tivizando o seu disc urso com qualquer outro (sem os mesmos cuidados investiga tivos), mas primand o por pesquisa s ma is precisas, inquirindo as fontes e agrupando as provas para se definir níveis mais aproximados de verdade, que segundo ele seriam possíveis dentro do discurso dos historiadores.

Diogo da Silva Roiz Universidade Estadual de Ma to Grosso do Sul

826 Estudos Feministas, Floria nópolis, 14(3): 819-841, setembro-dezembro/2006 